\title{
Relationships Between Indian Ocean Sea Surface Temperature and the Rainfall of Sri Lanka
}

\author{
By Ramasamy Suppiah \\ Institute of Geoscience, University of Tsukuba, Ibaraki, 305, Japan \\ (Manuscript received 3 July 1987, in revised form 30 September 1987)
}

\begin{abstract}
Spatial and temporal variations of the sea surface temperature (SST) over the Indian Ocean are examined by using empirical orthogonal function (EOF) analysis. The first EOF mode explains $20.54 \%$ of the total variance indicating positive values which reveal coherent interannual variations over the study area. Time coefficients of the first EOF mode show a strong relationship with the Pacific SST anomalies. Therefore, the El Niño/Southern Oscillation (ENSO) events are observed in the time coefficients of the first EOF mode almost simultaneously. Power spectrum analysis reveals a dominant peak ranging from 18 to 48 months which covers the quasi-biennial oscillation (QBO) and the dominant cycle in the Southern Oscillation phenomenon (30 to 40 months). The second and third EOF modes explain relatively less contributions, $5.6 \%$ and $5.1 \%$ of the total variance.

A weak positive correlation coefficient is observed between the time coefficients of the first EOF mode of SST anomalies and the time coefficients of the first EOF mode of the rainfall over Sri Lanka when all months are considered, but strong relationships are noticed for the months of October, November and December which coincide with the mature and decay stages of ENSO events. The positive relationships between SST anomalies of the Pacific and Indian Oceans and rainfall anomalies of the above mentioned months first appear in March and April, and then gradually build up towards the significant level in the concurrent months. In the case of the summer monsoon season, Arabian Sea SSTs, where strong seasonal and regional variations are found, strongly influence the rainfall of Sri Lanka, particularly striking in the southwestern quadrant of the island. Rainfall of this season has a significant positive correlation with the SST over the Arabian Sea during the concurrent period, but significant negative correlation with the previous months, before six months. The changes in the sign of the correlation coefficients occur in the months of November-December of the year before the summer monsoon, thus it may be useful to foreshadow the excess and deficit rainfall over Sri Lanka few months in advance.
\end{abstract}

\section{Introduction}

The influence of the sea surface temperature (SST) over the Arabian Sea has been an important factor for explaining the changes in the summer monsoon circulation and rainfall over India (Saha, 1974). Since a considerable amount of moisture comes from the Arabian Sea, it is reasonable to assume that the SST anomalies and wind over the oceanic area would have a marked influence over the weather and climate of India and Sri Lanka.

The relationships between SST over the Arabian Sea and monsoon rainfall were analyzed (C) 1988, Meteorological Society of Japan by Shukla and Misra (1977). They observed positive correlation coefficients particularly in the western and central India because a large amount of rainfall is caused by orographic effects. But the correlation coefficients are weak in the southern part. On the other hand, Shukla (1975) in an earlier study based on Geophysical Fluid Dynamics Laboratory (GFDL) general circulation model demonstrated that colder SST anomalies would increase rainfall over India. Sikka and Raghavan (1976) in their comments, pointed out that the GFDL model does not estimate rainfall well. Weare (1979) also found a weak negative relationship between Indian Ocean SST anomalies and Indian summer monsoon 
rainfall. The negative relationship remained unchanged when the correlation was calculated including the entire months' values and monsoon months' values.

Recently, Rasmusson and Carpenter (1983) examined the relationships between eastern equatorial Pacific SST anomalies and rainfall over India and Sri Lanka. They demonstrated a negative relationship between the SST anomalies and Indian summer monsoon rainfall and a positive relationship between SST anomalies and Sri Lankan autumnal rainfall. But their study lacks detail analyses on the relationships between SST anomalies and seasonal rainfall of Sri Lanka where the seasonality in rainfall is strong. Moreover, the relationships between the SST over Indian ocean and rainfall of Sri Lanka have not been studied in detail. Therefore, this study mainly focuses on the relationships between SST anomalies over the Indian Ocean and rainfall of Sri Lanka.

In the present study, first the spatial and temporal variations of SST anomalies for the period from 1949 to 1984 over the Indian Ocean are examined by using an empirical orthogonal function (EOF) analysis. Second, monthly and seasonal relationships between the time coefficients of the dominant modes of SST anomalies and of rainfall anomalies are analyzed. At last, lag relationships between second intermonsoon and summer monsoon seasons' rainfall, and SST anomalies over the Indian and Pacific Oceans are analyzed.

\section{Data and Method}

\subsection{Sea surface temperature data}

The SST data consist of monthly mean temperature values for grid points in each $5^{\circ}$ latitude by $5^{\circ}$ longitude area within the large region bounded by the parallels numbered $25^{\circ} \mathrm{N}$ and $5^{\circ} \mathrm{S}$ and by the meridians numbered $40^{\circ} \mathrm{E}$ and $100^{\circ} \mathrm{E}$ for the years 1949 to 1984 . The data set for the years 1949 to 1969 came from Weare (1979). The data set for the years 1970 to 1984 was received from the British Meteorological Office. Figure 1 depicts the selected grid points over the Indian Ocean.

\subsection{Rainfall data}

The basic rainfall data used in this study

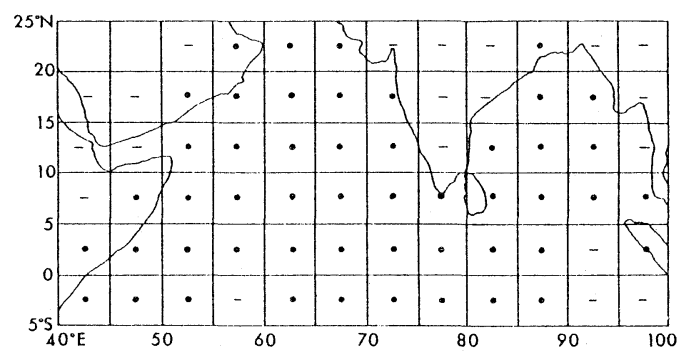

Fig. 1. Location of the selected grid points over the Indian Ocean.

consist of monthly mean rainfall values for 29 stations for the years 1949 to 1980. The data were obtained from a recent publication (Yoshino and Suppiah, 1982) and from manuscripts in the Department of Meteorology, Colombo, Sri Lanka. Selected rainfall stations and rainfall fluctuation regions used in this study are shown in Fig. 2. The rainfall fluctuation regions of Sri Lanka were delimited based on an EOF analysis on the non-seasonal rainfall

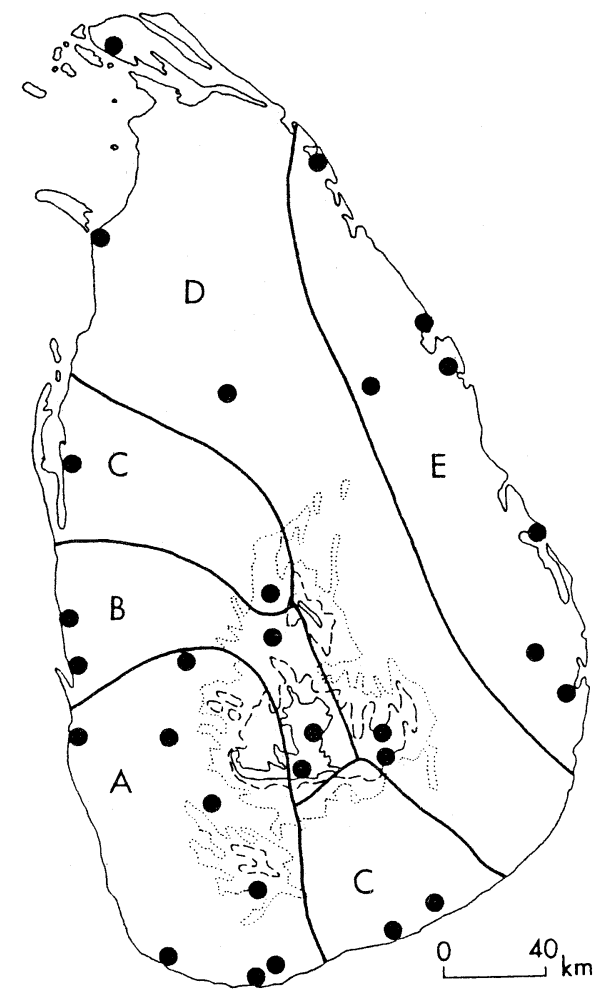

Fig. 2. Rainfall fluctuation regions of Sri Lanka. $A, B$, $C, D$ and $E$ represent the rainfall fluctuation regions used in the text (After Suppiah and Yoshino, 1984). 
fluctuations of the island in an earlier study (Suppiah and Yoshino, 1984).

\subsection{Southern Oscillation Index}

The Southern Oscillation Index (SOI) used in this study is the monthly value of the differences in mean-sea-level pressure between Tahiti $\left(18^{\circ} \mathrm{S}\right.$, $\left.150^{\circ} \mathrm{W}\right)$ and Darwin $\left(12^{\circ} \mathrm{S}, 131^{\circ} \mathrm{E}\right)$. The values were given by Parker (1983) and this index was recommended for the interannual climate variability studies by Chen (1982).

\subsection{Methods}

In this study, normalized values of rainfall and SST data are used in all calculations. For each station or oceanic grid point the deviation of a monthly value, from the long-term average is its anomaly. The anomalies were divided by the standard deviation of the specified month's time series. Thus the annual cycle is eliminated, permitting study of the non-seasonal variations. This procedure was applied both to rainfall and to SST data.

\subsection{EOF analysis}

An EOF analysis was applied to SST data to identify the dominant modes of its spatial and temporal aspects. A correlation matrix was used to derive a set of eigenvectors $\left(F_{i}\right)$, consisting of values $\left(F_{i}(s)\right)$ at each grid point $(s)$, which together make a spatial anomaly mode the amplitude $\left(a_{i}\right)$ of which varies from month to month $(t)$. The pattern $\mathrm{P}(t)$ in a month can be expressed as follows:

$$
P(s, t)=\sum_{i=1}^{n} a_{i}(t) F_{i}(s)
$$

The anomaly value $F_{i}(s)$ for each grid point is expressed in units of one standard deviation about the mean value at that grid point. The number of eigenvectors is limited to the number of grid points. The same method of analysis was applied to rainfall anomalies, and the dominant modes and their temporal variations were studied by Suppiah and Yoshino (1984).

\section{Results}

\subsection{Dominant modes in SST anomalies of the Indian Ocean}

Discussion on spatial and temporal aspects of SST anomalies is limited to the first EOF mode, because the other modes' contributions to the
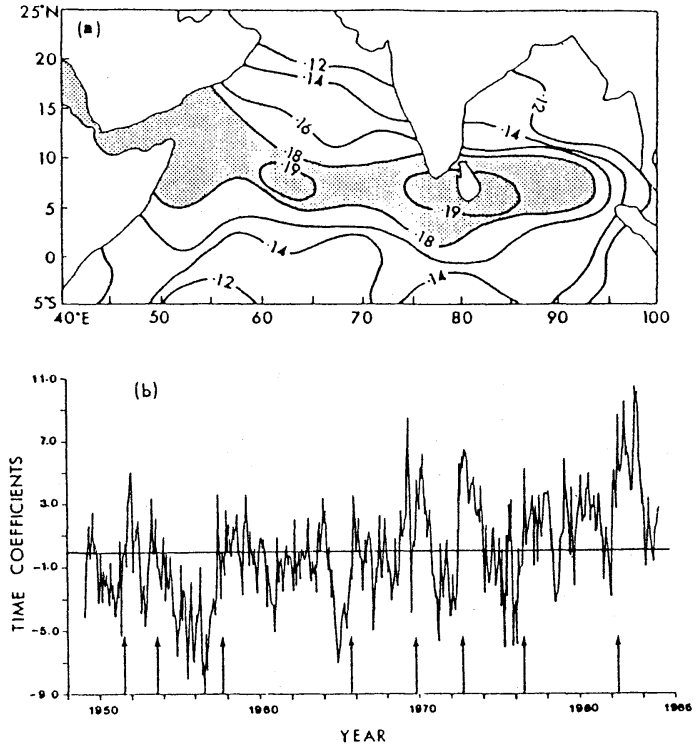

Fig. 3. The spatial pattern (a) and time coefficients (b) of the first EOF mode of the normalized SST anomalies of the Indian Ocean. Contributions greater than 0.18 are stippled in (a) and the vertical arrows denote the ENSO events in (b).

total variance are much smaller. The first mode of the EOF analysis on the SST anomalies of the Indian Ocean is given in Fig. 3(a) and its time coefficients are shown in Fig. 3(b). This mode explained $20.54 \%$ (Table 1) of the total variance, indicating positive values which showed that nearly coherent variations occurred over the entire analyzed area. This mode is similar to the first mode derived by Weare (1979). Looking at this mode, one can observe that large contributions are found along the main shipping routes. This shows that outside this area there is too much noise because the data coverage was very poor. Further, small deviations are found in the SST values over these areas.

The monthly contributions of the first three EOF modes are given in Table 2. It is clear that in the first EOF mode somewhat higher values are found for October and November, when the ocean surface temperature anomalies reach the maximum value. Particularly, the warm SST anomalies were clearly noticed during the El Niño years. Further, the time coefficients of the first EOF mode in the Indian Ocean in Fig. 3(b) indicate that the El Niño years $(1957,1965$, 
Table 1 Cumulative contributions (\%) of the ten eigenvectors.

\begin{tabular}{lrrrrrrrrrr}
\hline EOF & 1 & 2 & 3 & 4 & 5 & 6 & 7 & 8 & 9 & 10 \\
\hline VAR. & 20.54 & 5.62 & 5.12 & 3.72 & 3.18 & 2.94 & 2.90 & 2.58 & 2.40 & 2.32 \\
C.VAR. & 20.54 & 26.16 & 31.28 & 35.00 & 38.18 & 41.12 & 44.02 & 46.60 & 49.00 & 51.32 \\
\hline
\end{tabular}

Table 2 Monthly contributions (\%) of the first three eigenvectors.

\begin{tabular}{lccc}
\hline & EOF1 & EOF2 & EOF3 \\
\hline January & 14.8 & 3.3 & 3.2 \\
February & 11.9 & 5.5 & 2.9 \\
March & 12.1 & 6.3 & 4.0 \\
April & 11.2 & 5.9 & 4.0 \\
May & 15.0 & 3.0 & 2.8 \\
June & 17.3 & 4.0 & 4.3 \\
July & 16.4 & 3.1 & 3.5 \\
August & 12.2 & 3.0 & 4.4 \\
September & 12.6 & 5.7 & 4.9 \\
October & 21.6 & 2.3 & 2.8 \\
November & 18.2 & 3.7 & 2.1 \\
December & 14.7 & 3.2 & 5.5 \\
\hline
\end{tabular}

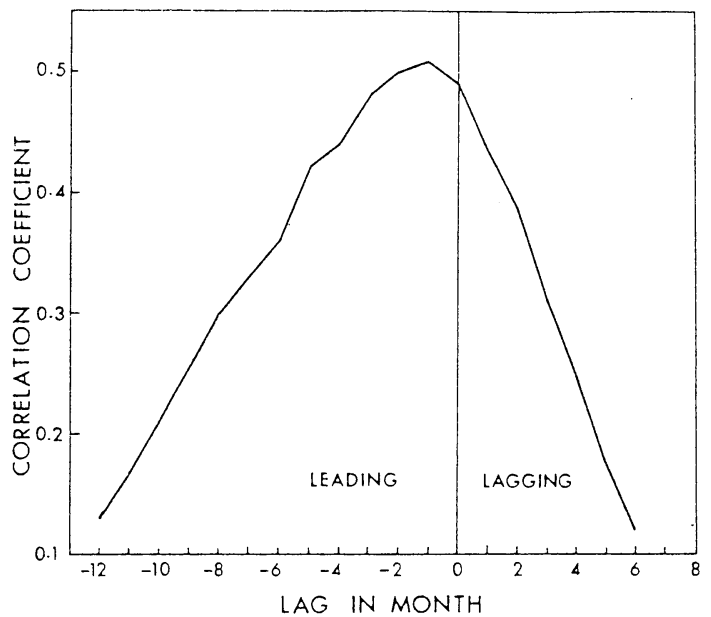

$1969,1972,1976$ and 1982) are clearly observed almost simultaneously in the Indian Ocean. Computed lag-correlation coefficients between the first EOF mode in the Indian Ocean and the first mode explained by Kawamura (1984) in the Pacific Ocean in Fig. 4 show strong correlation coefficients near zero lag. More strictly, the SST anomalies of the Pacific Ocean lead the SST anomalies of the Indian Ocean by one month. This result is consistent with the observations made by Hsiung and Newell (1983) who reported that the Indian and Pacific Oceans are heated almost simultaneously. Table 3 depicts the relationships between the Indian Ocean SST anomalies and the Pacific Ocean SST anomalies and also between the Indian Ocean SST anomalies and the SOI, which show strong correlation coefficients in the winter half year in

Fig. 4. Lag relationships between the time coefficients of the first EOF modes of the Pacific Ocean SST anomalies and of Indian Ocean SST anomalies. Leading/lagging means that the Pacific SST anomalies are leading or lagging the Indian Ocean anomalies.

the northern hemisphere when the SST anomalies reach the peak and decay stages in the tropical Pacific Ocean. But weak correlation coefficients are observed in the summer half year in the northern hemisphere when the southwest monsoon is influential. The correlation coefficients are comparatively weaker from April to September, though in some months they reach to 1 and $5 \%$ significant levels. Further, this observation is similar to those observations made by Bjerknes (1969) that the pressure and sea surface temperature variations over the Indian Ocean are associated with the Pacific Ocean

Table 3 Correlation coefficients between the Indian Ocean SST anomalies and eastern equatorial Pacific SST $(\mathrm{SST}(\dot{\mathrm{P}}))$ anomalies and between the Indian Ocean SST anomalies and the SOI.

\begin{tabular}{lrrrrrrrrrrrrr}
\multicolumn{10}{c}{ First EOF mode of the Indian Ocean SST } \\
\hline & Jan & Feb & Mar & Apr & May & Jun & Jul & Aug & Sep & Oct & Nov & Dec \\
& & & & & & & & & & \\
SOI & -0.53 & -0.62 & -0.41 & -0.31 & -0.32 & -0.42 & -0.45 & -0.32 & -0.25 & -0.70 & -0.48 & -0.67 \\
SST (P) & 0.78 & 0.49 & 0.41 & 0.29 & 0.40 & 0.44 & 0.36 & 0.22 & 0.24 & 0.57 & 0.71 & 0.61 \\
\hline
\end{tabular}

Significant levels for $1 \%$ and $5 \%$ are 0.45 and 0.35 respectively. $n=32$. 
pressure and SST variations.

Next, the time coefficients of the first EOF mode reveal an increasing trend between 1949 and 1984. This increasing trend might have been produced by various factors, such as greenhouse warming, instrumental errors, and the different data sets used in this study. However, Oort and Pan (1985) reported that more frequent ENSO and more intense events occurred during the period between 1950 and 1979 than in the period from 1920 to 1949 . That could indicate a trend for SST's to increase with time. Barnett (1984) found a similar trend over the north Indian Ocean and suggested an increase of $0.2^{\circ} \mathrm{C}$ between the early part of this century and recent times. In another study, Shukla (1987) reported a similar trend in SST's over the Indian Ocean becoming more steady after the 1940s.

Since the time coefficients of the first EOF mode indicate an increasing trend, first the trend was removed using a regression analysis and then a spectral analysis (Maximum Entropy Method) was applied to the time coefficients. Figure 5 depicts the spectral densities of the time coefficients of the first EOF mode. It shows a dominant peak with a broad hump comprising the period from 18 to 48 months, which apparently includes the quasi-biennial oscillation (QBO) and the SO cycle between 30 to 40 months. These results are consistent with the temporal variations of SST anomalies over the Pacific Ocean (Rasmusson and Carpenter, 1982) and of the Southern Oscillation (SO) phenomenon (Trenberth, 1976; Chen, 1982).

\subsection{Seasonal relationships between SST anomalies and rainfall}

The relationships between the rainfall of Sri Lanka and the time coefficients of the first EOF mode is weak when all months are considered due to seasonal variation in the sign of correlation coefficients, but they are strong for

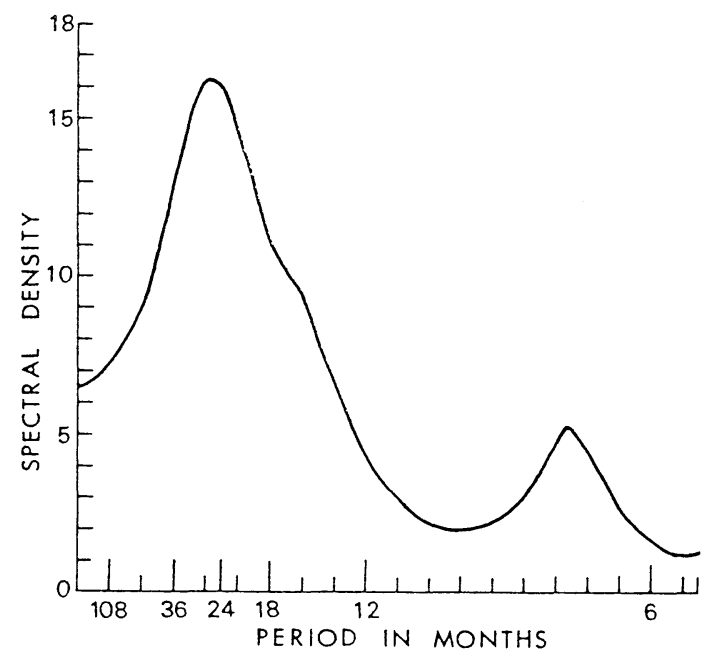

Fig. 5. Spectral densities (Maximum Entropy Method) of the time coefficients of the first EOF mode of the Indian Ocean SST anomalies. Periodicities below six months are omitted.

the months of October, November and December as shown in Table 4. Therefore, the seasonal relationships between the time coefficients of the first EOF mode of SST anomalies and rainfall anomalies are discussed. The relationship between the first inter-monsoon season (MarchApril) rainfall over Sri Lanka and the Indian Ocean SST anomalies is negative $(r=-0.12)$. The relationship between the summer monsoon rainfall (May-September) over Sri Lanka and the SST over the Indian Ocean is also negative $(r=-0.22)$ when the entire months are considered. However, the correlation coefficient reached the $5 \%$ significant level $(r=-0.38)$ when the peak monsoon months (July and August) were considered.

The relationship between the second intermonsoon season's (October-November) rainfall and the SST anomalies over the Indian Ocean is positive and significant at the $1 \%$ level $(r=0.61)$. Figs. 6 and 7 illustrate the lag-relationships

Table 4 Correlation coefficients between monthly time coefficients of the first EOF mode and rainfall of Sri Lanka.

\begin{tabular}{|c|c|c|c|c|c|c|c|c|c|c|c|c|}
\hline \multicolumn{13}{|c|}{ Sri Lanka rainfall } \\
\hline & Jan & Feb & Mar & Apr & May & Jun & Jul & Aug & Sep & Oct & Nov & Dec \\
\hline EOFI & -0.26 & -0.10 & -0.10 & -0.07 & -0.08 & -0.15 & -0.03 & 0.03 & 0.03 & 0.51 & 0.41 & 0.40 \\
\hline
\end{tabular}

Significant levels for $1 \%$ and $5 \%$ are 0.45 and 0.35 respectively. $\mathrm{n}=32$. 


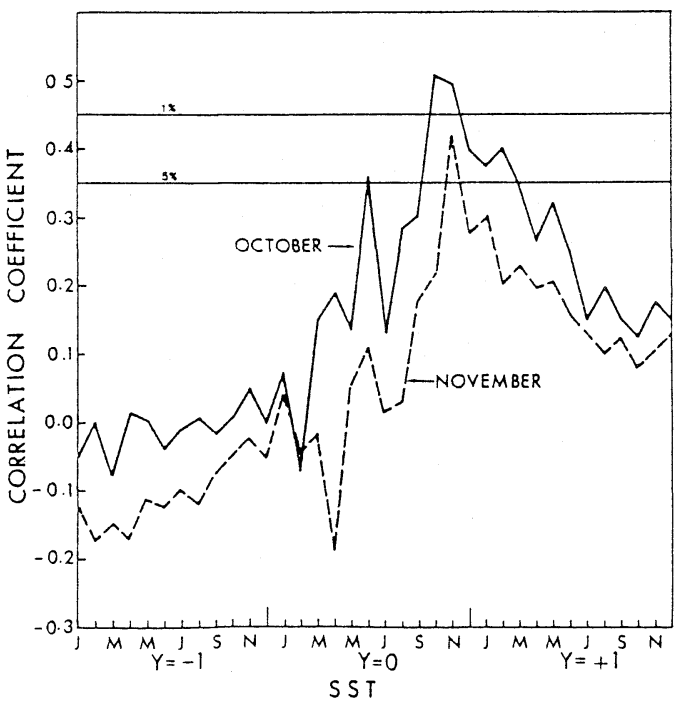

Fig. 6. Lag-relationships between the time coefficients of the first mode of SST anomalies of the Indian Ocean and the October and November rainfalls of Sri Lanka.

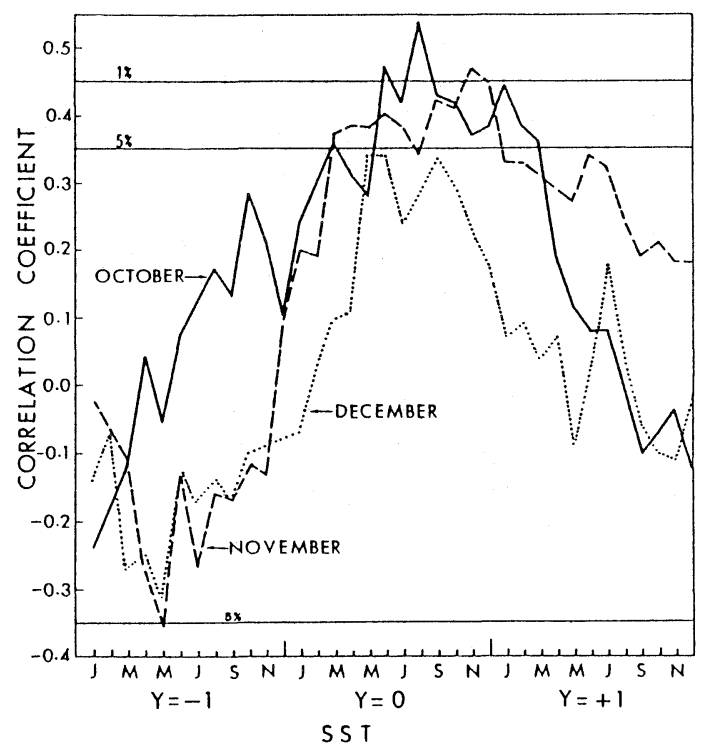

Fig. 7. Lag-relationships between the time coefficients of the first mode of SST anomalies of the Pacific Ocean and the October, November and December rainfalls of Sri Lanka.

between the time coefficients of the SST anomalies over the Indian and Pacific Oceans and rainfall, in which a positive relationship is found in the concurrent period. In these figures the preceding concurrent, and subsequent years are denoted as $Y=-1, Y=0$ and $Y=+1$, respectively. It is also clear from these figures that the months of October and November reveal stronger relationships with the mature stage of ENSO phenomenon, which causes large-scale variations in global climate. Moreover, the positive relationship is found at almost the same time because these two oceans show similar variations in their temporal aspects. In particular, the positive relationship between the second intermonsoon season and SSTs over the Indian and Pacific Oceans first appears in the month of March, when changes first appear in SSTs along the South American coast. The relationship gradually builds-up to the significant level in the concurrent period due to strong persistence in SST anomalies though there is a sudden decrease in the month of May, which is considered to be the beginning of the summer monsoon over Sri Lanka. Thus, it suggests that the global variations in SST anomalies strongly influence the second intermonsoon rainfall though the circulation features of the summer monsoon temporarily affect that relationship. This result also indicates that the monsoonal cooling effect on SSTs over the Indian Ocean, suggested by Shukla and Misra (1977) and Joseph and Pillai (1984), may partly influence the SSTs in the second intermonsoon season. The relationship between the northeast monsoon season (December-February) rainfall and SSTs over the Indian Ocean is positive (0.36), but it drops to 0.21 when the month of December is removed, which shows a significant positive correlation $(r=040)$ in Table 4.

\subsection{Arabian Sea SST and summer monsoon rainfall}

Since the relationships between the time coefficients of the dominant modes of SST anomalies and the summer monsoon rainfall of Sri Lanka are weak and it was made clear in earlier studies (Ramage, 1971; Shukla and Misra, 1977; Cadet and Diehl, 1984) that the long-term variations of summer monsoon rainfall are apparently related to the variations in the trade wind belt of the southern hemisphere, meteorological parameters of the Arabian Sea and along the East African coast, correlation coefficients are worked out between three months values of SST over the Arabian Sea where seasonal variations are stronger and summer monsoon 


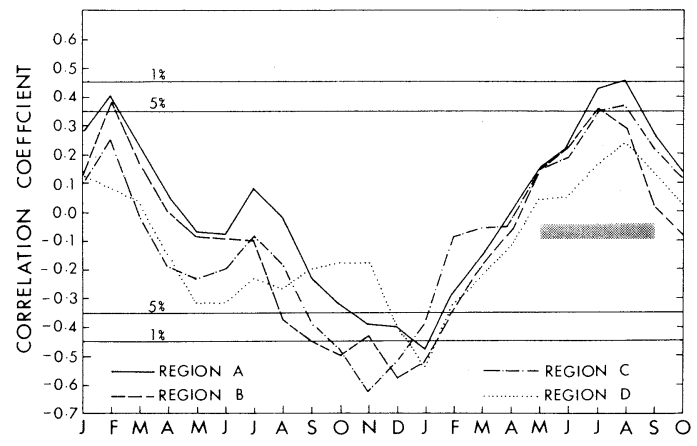

Fig. 8. Correlation coefficients between summer monsoon rainfall and three month means of SSTs for the grid point of $50^{\circ}-55^{\circ} \mathrm{E}, 5^{\circ} \mathrm{S}-0^{\circ}$. The central month of three month periods are indicated on the abscissa. The stippled area indicates the summer monsoon season.

rainfall over Sri Lanka.

Figure. 8 illustrates the lag-relationships between the rainfall over Sri Lanka during the summer monsoon season and a selected grid point over the Arabian Sea $\left(50-55^{\circ} \mathrm{E}, 5^{\circ} \mathrm{S}-0^{\circ}\right)$, an area which shows higher correlation coefficient when compared with those other grid points (see Fig. 1). It reveals that summer monsoon rainfall is simultaneously positively correlated with SSTs over the Arabian Sea but negatively correlated with the previous six months. Moreover, it shows that the sign of the correlation coefficients changes in the period from November to December of the year before the monsoon. Nicholls (1983) also found changes in the sign of the correlation coefficients around this time between SSTs over the Indonesian area and Indian summer monsoon. Kung and Sharif (1982) used the preceding winter SST over the Arabian Sea in their model to forecast Indian summer monsoon rainfall and onset date. The pattern of relationship is stronger in the rainfall fluctuation regions of $A, B$ and $C$ shown in Fig. 2 , where much moisture for rainfall is received from the Arabian Sea, but weaker in the region $D$. Although the pattern of relationship exists in the region $\mathrm{E}$, the correlation coefficients do not reach the statistically significant level. Regions $A$ and $B$ experience much rainfall due to orographic effects of the central highlands of Sri Lanka but the Regions $C, D$ and $E$ receive less rainfall due to the effects of a local wind called 'Kachchan'. Strong kachchan winds cause high air temperature and low relative humidity and rainfall over the regions of $D$ and $E$.

The pattern of relationship between SSTs over the Arabian Sea and summer monsoon rainfall over Sri Lanka is not unreasonable. Shukla and Misra (1977) observed a positive relationship between Indian monsoon rainfall and SST over the Arabian Sea and at the same time they reported a negative relationship between SST and wind speed. In their analyses, the lag relationship between SST and rainfall is stronger by one month, where the northern current of the Arabian Sea branch is dominant (for details of the currents of the Arabian Sea branch see Miller and Keshavamurthy, (1968) and Findlater (1969)). The northern current of the Arabian Sea branch gives much rainfall to Konkan coast and central India associated with well-developed subtropical cyclone (Ramage, 1971). But the relationship is weak where the southern current of the Arabian Sea is dominant. As reported in earlier studies (Ramage, 1971; Shukla and Misra, 1977; Weare, 1979), negative SST anomalies over the Arabian Sea could strengthen the high pressure over the Oceanic area and consequently cause a strong pressure gradient between the Arabian Sea and central India and therefore lead to strong summer monsoon circulation. Such a condition is associated with the SO phase which gradually strengthens from the preceding winter months (Cadet and Diehl, 1984; Cadet, 1985). These two currents act in out-of-phase relationship in their wind velocities. Moreover, a strong negative relationship between SST over this area and wind speed over Colombo is observed (Suppiah, 1987) which is striking in the monsoon peak months (July and August) $(r=-0.57, n=20)$. At the same time a negative relationship between wind speed at the $850 \mathrm{mb}$ level over Colombo, where the southern current of the low-level jet (Findlater, 1969) is detected, and summer monsoon rainfall over Sri Lanka is also noticed during this period $(r=-0.56, n=20)$ which is significant at the $1 \%$ level. During the summer monsoon season, stronger winds are observed from west to northwest directions and they are relatively dry, because strong summer monsoon winds associated with the southern current of the Arabian Sea branch bring wet conditions to the windward slopes of the Western Ghats mountain 
range in India and blow with less moisture over Sri Lanka. On the other hand, weak summer monsoon winds are frequently observed from southwest direction with ample moisture. The above mentioned out-of-phase relationship in wind speed in the Arabian Sea branch currents are associated with strong or normal summer monsoon circulations and thus cause a positive relationship between the rainfall of India and Sri Lanka during this season. During a weak monsoon condition the contrast is not clear. From the results mentioned above, it should be emphasized that low (high) SSTs in the previous winter months could lead to a strong (weak) summer monsoon circulation that in turn leads to a strong (weak) contrast in wind speed between the two currents of the Arabian Sea. As a consequence, a strong (weak) southern current of the Arabian Sea branch could bring below(above-) normal rainfall over Sri Lanka and above- (below-) normal rainfall on the Malabar coast in India.

\section{Conclusions}

Analyses on the spatial and temporal variations of SST anomalies over the Indian Ocean and on the relationships between SST anomalies over the Indian and Pacific Oceans and seasonal rainfall led to the following conclusions:

The first EOF mode of the SST anomalies over the Indian Ocean explained $20.54 \%$ of the total variance indicating positive contributions over the study area. It should be pointed out here that large contributions are confined to the shipping routes where there is less noise in the data, but the contributions are smaller in other areas where the noise is large and the deviations from the climatological mean are also rather less.

Time coefficients of the first EOF mode showed a strong relationship with the Pacific SST anomalies and, therefore, the ENSO events over the Indian Ocean are clearly observed simultaneously. Furthermore, time coefficients of the first mode revealed an increasing trend in recent years. Temporal variations in SST anomalies revealed a dominant peak ranging from 18 to 48 months which includes the QBO and SO cycle.

The second and third EOF modes of the SST anomalies explained 5.6 and $5.1 \%$ of the total variance respectively.
The relationship between the time coefficients of the first EOF mode of the SST anomalies of the Indian Ocean and the first EOF mode of the rainfall anomalies over Sri Lanka is positive and weak when all months are considered. This is because of the seasonal variations in the sign of the correlations. However, the relationship is stronger for the months of October, November and December.

The relationships between the first intermonsoon and summer monsoon seasons' rainfall anomalies and SST anomalies are negative but weak. The relationship between the SST anomalies and rainfall anomalies of the second intermonsoon season is positive and significant at the $1 \%$ level. Since the positive relationship between SST anomalies of the Indian and Pacific Oceans and the rainfall of the second intermonsoon season gradually builds-up from the month of March and the Pacific Ocean SST anomalies lead the Indian Ocean SST anomalies by one month, Pacific Ocean SST anomalies have a longer lead time to foreshadow the rainfall anomalies. The relationship between the SST anomalies and the northeast monsoon rainfall is also positive but weak. In case of the summer monsoon, a significant positive relationship is found in the simultaneous period but a significant negative relationship is observed between summer monsoon rainfall and previous winter SSTs over the Arabian Sea. This may help to foreshadow the excess and deficit summer monsoon rainfall over Sri Lanka a few months in advance.

\section{Acknowledgments}

I am grateful to Professor M.M. Yoshino, University of Tsukuba, for his suggestions and encouragements on this study. Sincere thanks are due to Professor B.C. Weare, University of California, Davis and Dr. D.E. Parker, Meteorological Office, Bracknell, England for providing the SST data, and to the Director, Department of Meteorology, Colombo for providing the rainfall data. Thanks are due to anonymous referees who made useful comments on the manuscript. Most of the calculations were done at the Science Information and Processing Center of the University of Tsukuba. 


\section{References}

Barnett, T.P., 1984: Long-term trends in surface temperature over the oceans. Mon. Wea. Rev., 112, 303-312.

Bjerknes, J., 1969: Atmospheric teleconnections from the equatorial Pacific. Mon. Wea. Rev., 97, 163-172.

Cadet, D.L., 1985: The Southern Oscillation over the Indian Ocean. J. Climatolo., 5, 189-212.

and B.C. Diehl, 1984: Interannual variability of surface fields over the Indian Ocean during recent decades. Mon. Wea. Rev., 112, 1921-1935.

Chen, W.Y., 1982: Assessment of Southern Oscillation sea-level pressure indices. Mon. Wea. Rev., 110, 800-807.

Findlater, J., 1969: A major low-level air current near the Indian Ocean during the northern summer. Quart. J. R. Met. Soc., 95, 362-380.

Hsuing, J. and R.E. Newell, 1983: Principal nonseasonal modes of variation of global sea surface temperature. J. Phys. Oceanogr., 13, 1957-1967.

Joseph, P.V. and P.V. Pillai, 1984: Air-sea interaction on a seasonal scale over north Indian Ocean - Part 1: Inter-annual variations of sea surface temperature and Indian summer monsoon rainfall. Mausam, 35, 323-330.

Kawamura, R., 1984: Relation between atmospheric circulation and dominant sea surface temperature anomaly patterns in the North Pacific during the Northern Hemisphere winter. J. Meteor. Soc. Japan, 62, 910-916.

Kung, E.C. and T.A. Sharif, 1982: Long-range forecasting of the Indian summer monsoon onset and rainfall with upper air parameters and sea surface temperature. J. Meteor. Soc. Japan, 60, 672-681.

Miller, F.R. and R.N. Keshavamurthy, 1968: Structure of an Arabian Sea monsoon system. International Indian Ocean Expedition, Meteorological Monographs, East-West Center Press, Honolulu, No. 1, 1-94.

Nicholls, N., 1983: Predicting Indian monsoon rainfall from sea-surface temperature in the Indonesianorth Australia area. Nature, 306, 576-577.

Oort, A.H. and Y-H. Pan, 1985: Diagnosis of historical ENSO events. Proc. First WMO Workshop on the Diagnosis and Prediction of Monthly and Seasonal
Atmospheric Variations Over the Globe. College Park, MD, U.S.A. 29th July 2nd August, 1985.

Parker, D.E., 1983: Documentation of a Southern Oscillation index. Meteor. Mag., 112, 184-188.

Ramage, C.S., 1971: Monsoon meteorology. Academic Press, New York and London, 296p.

Rasmusson, E.M. and T.H. Carpenter, 1982: Variations in tropical sea surface temperature and surface wind fields associated with the Southern Oscillation/El Niño. Mon. Wea. Rev., 110, 354-384.

$\longrightarrow$ 1983: The relationship between eastern equatorial Pacific sea surface temperatures and rainfall over India and Sri Lanka. Mon. Wea. Rev., 111, 517-528.

Saha, K., 1974: Some aspects of the Arabian Sea summer monsoon. Tellus, 26, 465-476.

Shukla, J., 1975: Effect of Arabian sea-surface temperature anomaly on Indian summer monsoon: A numerical experiment with the GFDL model. $J$. Atmos. Sci., 32, 503-511.

- 1987: Interannual variability of monsoons. In: Monsoons, Ed. by J.S. Fein and P.L. Stephens, Wiley \& Sons, 399-463.

and M. Misra, 1977: Relationships between sea surface temperature and wind speed over the central Arabian Sea, and monsoon rainfall over India. Mon. Wea. Rev., 105, 998-1002.

Sikka, D.R. and K. Raghavan, 1976: Comments on effects of Arabian sea-surface temperature anomaly on Indian summer monsoon: A numerical experiment with the GFDL model. J. Atmos. Sci., 33, 2252-2253.

Suppiah, R., 1987: Atmospheric circulation variations and the rainfall of Sri Lanka. Ph.D. Thesis, Institute of Geoscience, University of Tsukuba, 151p. and M.M. Yoshino, 1984: Rainfall variations of SriLanka, Part 1: Spatial and Temporal patterns. Arch. Met. Geoph. Biocl., Ser. B, 34, 329-340.

Trenberth, K.E., 1976: Spatial and temporal variations of the Southern Oscillation. Quart. J.R. Met. Soc., 102, 639-653.

Weare, B.C., 1979: A statistical study of the relationships between ocean surface temperatures and the Indian monsoon. J. Atmos. Sci., 36, 2279-2291.

Yoshino, M.M. and R. Suppiah, 1982: Climatic records of monsoon Asia. Climatolo. Notes, No. 31, 81 p. 


\title{
インド洋の海面水温とスリランカの降水量との関係
}

\author{
Ramasamy Suppiah \\ (筑波大学地球科学系)
}

経験淔交関数（EOF）解析を適用して、インド洋に抢ける海面水温（SST）の時空間変動を調べ

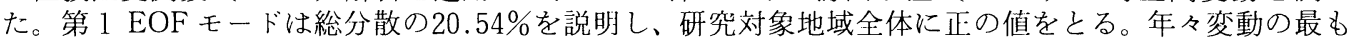
卓越した成分を表す第 1 EOF モードの時間係数は太平洋のSST アノマリーと密接に関連している。そ れゆ光、El Niño/Southern Oscillation (ENSO)イベントは、太平洋と同時期に第 1 EOF モードの時間 係数に現わ机る。SSTのスペクトル解析の結果によると、準 2 年周期（QBO）を含む18-48ヶ月の周期 帯と 30-40ケ月の哃期帯（南力振動）が卓越している。第 $2 、 3$ EOF モードは、それぞれ総分散の 5 . $6 \% 、 5.1 \%$ を説明しているが、相対的に寄与率は低い。

SSTアノマリーの第 $1 \mathrm{EOF} モ$ ードとスリランカにおける降水量の第 $1 \mathrm{EOF} モ$ ードの時系列を比較す ると、すべての月について弱い正の相関関係が存在する。特に高い相関はENSO イベントの完熟期、衰 退期に対忍する10月、11月、12月にみられる。太平洋およびインド洋のSSTアノマリーとスリランカの 降水量アノマリーとの正の相関は最初に 3 月、4 月に壮現し、徐々に有意水準に達してくる。夏季モン スーンの時には、アラビア海のSST はスリランカ、特に南西部の降水量に大きな影響を与えている。こ の季節の降水量は、同時期のアラビア海の SST と有意な正の相関があるが、6ケ月前の SST とは有意 な負の相関が存在する。相関係数の符号の反転は夏季モンスーンの前年の11、12月に生じる。それゆ光、 数ケ月後のスリランカの降水量の増加・減少を予測するのに有用かもしれない。 